\title{
Sizing and Evaluation of Battery Energy Storage Integrated with Photovoltaic Systems
}

\author{
Paulo A. V. Vieira, Felipe P. G. Silva, Bruna F. Pinheiro, and Edson C. Bortoni*
}

\begin{abstract}
This paper provides a review of the most common energy storage technologies and analysis of the impact of battery energy storage (BES) in a distribution network with penetration of photovoltaic. In order to reduce the intermittence impacts caused by solar panels (PV), is proposed the use an energy storage elements to stabilize the energy produced, dependent of the irradiation and temperature. Different storage technologies were considered as a function of the costs. A $100 \mathrm{~kW}$ PV system with integration of an energy storage was used for the simulated and analysis.
\end{abstract}

Index Terms - Photovoltaic power plants, energy storage, photovoltaic generation, battery.

\section{INTRODUCTION}

$\mathrm{W}$ ITH the continuous growth of consumption of electric energy in the world and the use of exhaustible resources, new forms of generation have been developed for the reduction of the environmental impact.

Worldwide, photovoltaic energy systems have been growing exponentially since the end of the last decade. By 2015 the total installed capacity was $227 \mathrm{GWp}$. China has now led a solar photovoltaic capacity of $43.5 \mathrm{GWp}$, followed by Germany with 39.7 GWp, Japan with $34.4 \mathrm{GWp}$, the United States with 25.6 GWp. According to data from the Ministry of Mines and Energy (MME), at the end of 2016, Brazil has 81 MW of installed PV, with $24 \mathrm{MWp}$ of centralized generation and 57 MWp of distributed generation [1].

However, the availability of variable resources often does not positively correlate with the power demand. Therefore, the use of energy storage systems (ESS) together as renewable sources become indispensable for generation control.

The ESS allows for a movement of the energy use over time, since ESS enables to generate and to consume at different times [2]. Therefore, this process allows electricity to be used in periods of high demand, low generation cost and that is used in periods of high consumption or acting as a backup in cases where the main generation becomes inaccessible [3]. The use of ESS makes possible to manage the reliability and resilience of variable generation systems and improve the functionality of smart grids.

Manuscript received January 16, 2018; revised March 23, 2018; accepted April 28, 2018.

Paulo A. V. Vieira, Felipe P. G. Silva, abd Bruna F. Pinheiro are student member of IEEE, and Edson C. Bortoni, is Senior Member of IEEE, are with the Itajubá Federal Univeristy, Itajubá, MG 37500-903 Brazil, (e-mail: pauloviana@unifei.edu.br,_fepgs@unifei.edu.br,_brunaf.pinheiro @unifei.edu.br, bortoni@unifei.edu.br)

*Corresponding author
Therefore, they disseminate effectively the renewable energy sources, which consequently to improve the effectiveness of existing resources.

In addition, the renewables and storage helps to reduce the use of fossil fuels, reducing $\mathrm{CO}_{2}$, greenhouse gases, and global warming. As a result, ESS has recently attracted the attention of governments, stakeholders, researchers, and investors, aiming at improving the performance of the energy systems.

This paper is organized as follows. In section II, energy storage is discussed. In section III, the methodology and study of the case are presented. In section IV, the results and discussions are presented. Concluding remarks are presented in section V.

\section{ENERGy StORAGE TECHNOLOGIES}

Energy storage is not a new development; more than two centuries ago Galvani discovered bioelectricity, around 1800 Alessandro Volta invented the modern battery, but only in 1836 they were used in telegraph networks. In 1880 lead-acid batteries were used to feed private night loads in New York in areas with direct current (DC) system. The first large-scale storage system was built in 1929 as a 31 MW pumped storage at Rocky River Power Plant, Connecticut Light \& Power [4].

Some ESS technologies store energy in the DC form being necessary the use of DC/AC converter, such as batteries, and supercapacitors. Two major factors characterize the use of energy storage technology system. One is the amount of energy that can be stored, that is a characteristic of the storage device itself [4]. The other is the rate at which the energy can be transferred into or out of the storage device. The selected technology depends mainly on the peak power rating of the power conversion unit but is also impacted by the response rate of the storage device itself.

The possible benefits include transmission enhancement, power oscillation damping, dynamic voltage stability, spinning reserve, under-frequency load shedding reduction, and power quality improvement [4-5]. On the other hand, batteries can be relatively expensive and there are environmental concerns due to toxic gas generation during charge/discharge time, risk of explosion due a higher temperature and some batteries technologies must be replaced every 10 to 15 years due the end of their cycle of life [5-6].

Work has been conducted to investigate ESS technologies, i.e., their functions, response times, and suitable storage durations. In general, it is based on the form that energy is stored in the system, which can be mechanical (pumped hydroelectric storage, compressed air energy storage and flywheels), electrochemical (conventional rechargeable batteries and flow batteries), electrical (capacitors, super- 
capacitors and superconducting magnetic energy storage), thermochemical (solar fuels), chemical (hydrogen storage with fuel cells) or thermal energy storage (sensible heat storage and latent heat storage) [7-9]. Figure 1 summarizes technologies of energy storage applications [7].

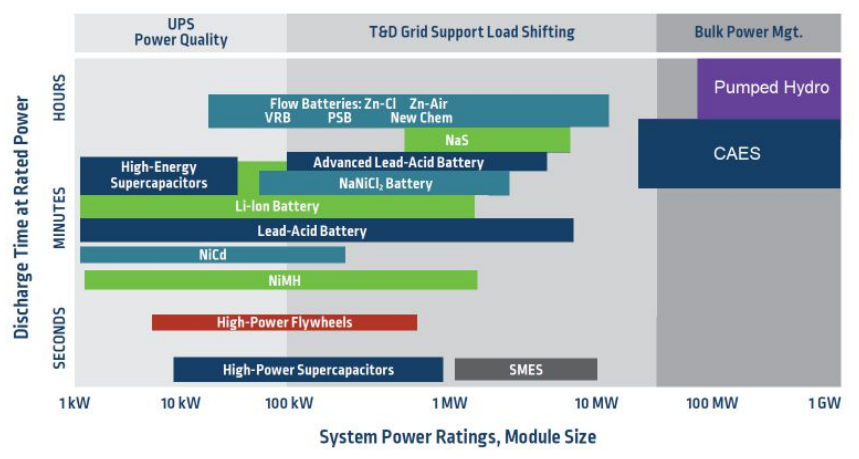

Fig. 1. Position of Energy Storage Technologies.

Analysts expect advancements in ESS to occur with the maturation of new technologies, such as metal-air batteries, and the application of new materials and designs to proven technologies, like lead-acid. As an example, Tesla Inc. installed in South Australia in 2017 the largest Lithium-ion battery energy storage system (BESS) in the world with $100 \mathrm{MW}$ of capacity, this system works as a backup to the power system [10]. In general, energy storage technologies are divided into electrochemical, electromechanical, thermal, hydrogen and electrical. Each technology has its strengths, limitations, and appropriateness for the large and diverse set of applications for ESS [11-14].

Nowadays, batteries are the most widespread electrical energy storage technology. In this context, this paper proposes the sizing of the photovoltaic plant and the system BESS bank. A functional analysis of the operation of a photovoltaic system with and without energy storage is conducted via modeling and simulation.

Therefore, Brazilian national electricity agency (ANEEL) is looking forward to safe incorporate and the increasing of the participation of renewable energy generation and storage in the Brazilian power system.

\section{METHODOLOGY}

In order to compare the operation of BES and to show the benefits of the use of these in photovoltaic systems, a detailed model of a $100 \mathrm{~kW}$ Grid-Connected PV Array was developed and adapted using Matlab/Simulink [15-16]. This PV generation system is connected to the grid with respective simulation parameters connected to the ESS is shown in Fig. 2. The scenarios of the simulations are PV System without Energy Storage (Case 1) and PV System with Energy Storage (Case 2).

The design of the PV system depends on the meteorological characteristics of the region and on the connected loads. The city of Itabira, Brazil, is taken as an example. Solar radiation data were used, more specifically, the average irradiation rates [17]. In addition, it was considered illumination and household appliances of a small residential village to calculate the daily consumption of the loads. Table I presents the input parameters and the losses for the proposed system, the losses values are standard values [18]. PV sizing considers the voltage levels, the estimated overall losses, and the irradiation conditions of the region. Standard values were used to estimate the losses in the wiring, battery bank, converter DC/DC, and in the inverter [18].

TABLE I

SYSTEM CHARACTERISTICS

\begin{tabular}{lc}
\hline \hline \multicolumn{1}{c}{ Parameters } & Value \\
\hline Total Energy consumed per day $\left(E_{c}\right)$ & $146,2 \mathrm{Wh}$ \\
Power consumed per day $\left(P_{c}\right)$ & $19,850 \mathrm{~W}$ \\
DC nominal voltage $\left(V_{d c}\right)$ & $120 \mathrm{~V}$ \\
Cable Efficiency $\left(\eta_{C}\right)$ & $98 \%$ \\
Battery Bank Efficiency $\left(\eta_{B}\right)$ & $90 \%$ \\
Inverter Efficiency $\left(\eta_{\text {Inv }}\right)$ & $95 \%$ \\
Converter Efficiency $\left(\eta_{\text {Conv }}\right)$ & $90 \%$ \\
\hline \hline
\end{tabular}

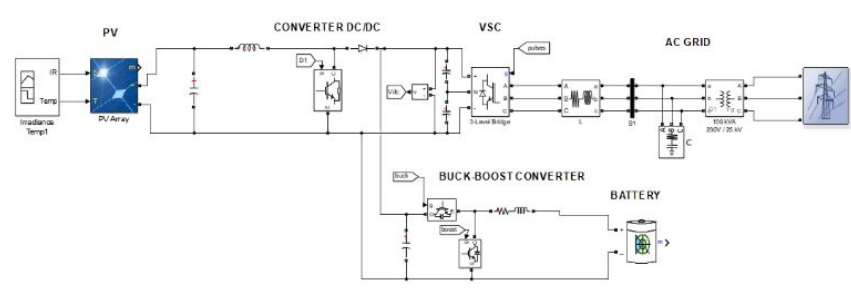

Fig. 2. System configuration with energy storage.

The calculation of the minimum capacity of PV modules is based on the solar energy accumulated during the day. The number of hours of full sun $-F S$ (h/day) - reflects the number of hours that solar irradiation remains constant and equal to 1 $\mathrm{kWh} / \mathrm{m}^{2}$, i.e., the resulting energy is equivalent to the energy accumulated during the day.

A daily irradiation rate of $4.35 \mathrm{kWh} / \mathrm{m}^{2}$ (lowest irradiance value) was used and is produced along 4 hours and 21 minutes of a constant incident power equal to $1 \mathrm{~kW} / \mathrm{m}^{2}$. Therefore, the minimum power of the generator $\left(P_{m}\right)$, as shown in (1), is calculated.

$$
P_{m}=\frac{E_{c}}{F S}
$$

Considering the efficiency of the system components, the power $\left(P_{C R}\right)$ is:

$$
P_{C R}=\frac{P_{m}}{\eta_{C} \eta_{B} \eta_{\text {Inv }} \eta_{\text {Conv }}}
$$

The proper sizing of the number of photovoltaic panels depends on the battery autonomy, in the case of an isolated / off-grid system. Therefore, the need for energy storage for night time use and at intervals with solar radiation below the average is considered. A 2-day autonomy (A) was defined according to ANEEL's rule 83. In addition, the need for complete recharge in 3 normal days (B) of the sun in maximum discharge condition must be considered [19]. The autonomy power $\left(P_{\text {aut }}\right)$ for a 2-day run plus one day with the extra power for charging, result in (3). 


$$
P_{\text {out }}=P_{C R}\left(1+\frac{A}{B}\right)
$$

Numerous commercial photovoltaic panels are currently commercially available. The proper choice of panel power directly influences the cost of the system, since the number of panels for the generation required by the load varies with their individual power. The panels chosen were SunPower SPR-305WHT-D, with polycrystalline solar cells, each $305 \mathrm{~W}\left(P_{P n}\right)$ and $15 \%$ efficiency, as presented in Table 2 [15].

TABLE II

PV CHARACTERISTICS

\begin{tabular}{lc}
\hline \multicolumn{1}{c}{ Parameters } & Value \\
\hline Minimum Power of the Generator $\left(P_{m}\right)$ & $33,609.19 \mathrm{~W}$ \\
Corrected Power $\left(P_{C R}\right)$ & $44,568.02 \mathrm{~W}$ \\
Autonomy Power $\left(P_{\text {aut }}\right)$ & $74,280.04 \mathrm{~W}$ \\
Project Power $\left(P_{P}\right)$ & $81,708.05 \mathrm{~W}$ \\
Number of panels $(N)$ & 330 \\
\hline \hline
\end{tabular}

In addition, ANEEL's rule 482 recommends a $10 \%$ safeguard [19]. Therefore, the project power (PP) is:

$$
P_{P}=P_{\text {out }}+10 \%
$$

The minimum required a number of panels $(N)$ to meet the average daily load and energy storage is:

$$
N=\frac{P_{P}}{P_{P n}}
$$

The complete photovoltaic arrangement considering future load additions was sized as 5 modules in series and 66 parallels, adding a voltage of $273.5 \mathrm{~V}$ and with a total generation capacity of $100.6 \mathrm{~kW}$ at $25{ }^{\circ} \mathrm{C}$ at the solar irradiation of $1 \mathrm{~kW} / \mathrm{m}^{2}$. The irradiation and temperature input data for the PV is shown in Fig. 3. Results are also presented in Table II.
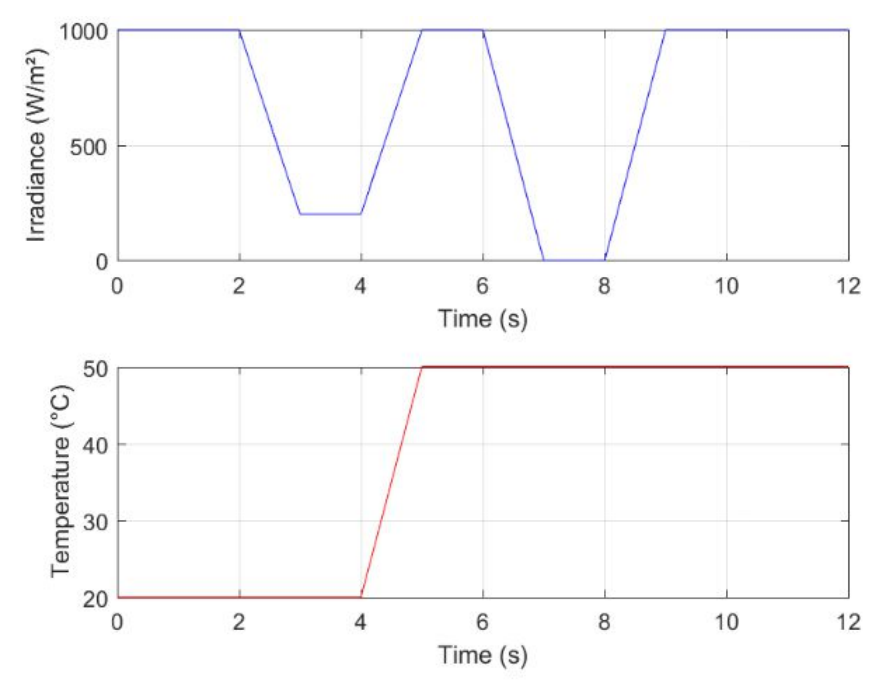

Fig. 1. Curve of irradiation and temperature variation.

\section{SIZING THE BATTERY BANK}

As the solar incidence is variable and dependent on climatic conditions, the use of a storage system that guarantees the energy supply to the load at night or in periods with sun deficit is essential. The battery bank considers two important parameters: the system autonomy and the accepted discharge depth. The autonomy of the storage system corresponds to the number of days in which the energy stored in the battery bank is enough to supply the demand without any energy replacement by the photovoltaic panels [20].

The voltage and current delivered to the grid are shown in Fig. 10. The voltage and current are constant when compared to the system without the battery. The basis are $25 \mathrm{kV}$ and $3.01 \mathrm{~A}$.

This parameter represents the autonomy of the PV system. However, the increase in the number of days of autonomy of the system increases the costs of the battery bank and, consequently, of the system [21].

The depth of discharge (DoD) of a battery is directly linked to its life. A DoD of $15 \%$ was considered for the energy storage system, for a minimum operation of two years. A battery model unity with $155 \mathrm{Ah}\left(I_{b}\right)$ was chosen for the battery bank. The daily load current $\left(I_{l}\right)$ is calculated in (6):

$$
I_{l}=\frac{P}{V_{d c}}
$$

The corrected consumption current $\left(I_{C C}\right)$ is

$$
I_{C C}=\frac{I_{l}}{\eta_{C} \eta_{B} \eta_{I n v} \eta_{C o n v}}
$$

Therefore, the total current $\left(I_{t}\right)$ of the battery bank is (8):

$$
I_{t}=\frac{I_{C C}}{D o D}
$$

It was defined that the battery banks will be composed of 10 parallel strings with 10 series of batteries of $155 \mathrm{Ah}$, totalizing $120 \mathrm{~V}$ on the DC bus and a current of $1550 \mathrm{Ah}$. The parameters used in the battery models can also be extracted from manufacturer's data [18] and are shown in Table III.

\section{Bidirectional BoOst CONVERTER AND DC-DC CONVERTER}

A bidirectional boost converter was used to control the power flow. These converters have diodes between the IGBT terminals, which allow current flow in the 2 directions.

It is desired constant power flow to the network of $80 \mathrm{~kW}$, regardless of the generation variations in the panel, complement by the battery [15-16]. The gains of the controller are calculated in [21]. This signal is compared to a triangle wave, where the PWM signal is generated, in complementation, for both IGBTs [22-23]. 
TABLE III

BATTERY CHARACTERISTICS

\begin{tabular}{lc}
\hline \multicolumn{1}{c}{ Parameter } & Value \\
\hline Load Current $\left(I_{l}\right)$ & $165.41 \mathrm{Ah}$ \\
Corrected Consumption Current $\left(I_{C C}\right)$ & $219.35 \mathrm{Ah}$ \\
Total Current $\left(I_{t}\right)$ & $1462.35 \mathrm{Ah}$ \\
\hline \hline
\end{tabular}

The DC-DC converter has the purpose of increasing the voltage generated by the photovoltaic panels in order to generate a maximum of $500 \mathrm{~V}$. The control on the PV is done through a Maximum Power Point Tracker (MPPT) algorithm that maintains the panel at the maximum point at all levels of solar radiation and temperature changes. The algorithm used in the model is incremental conductance, which has quicker response compared to other known algorithms [15].

\section{RESUlts AND DisCusSIONS}

Figure 4 shows the behavior of DC voltage and current for the case 1 . The current is zero in the absence of PV generation, as the current is proportional to the irradiation, therefore, its behavior is similar to the irradiation curve. On the other hand, the voltage is almost constant, due to the control of the MPPT. The MPPT is more sensitive to temperature variations. Therefore, the MPPT is fast for irradiation variations and is slower for temperature variations.
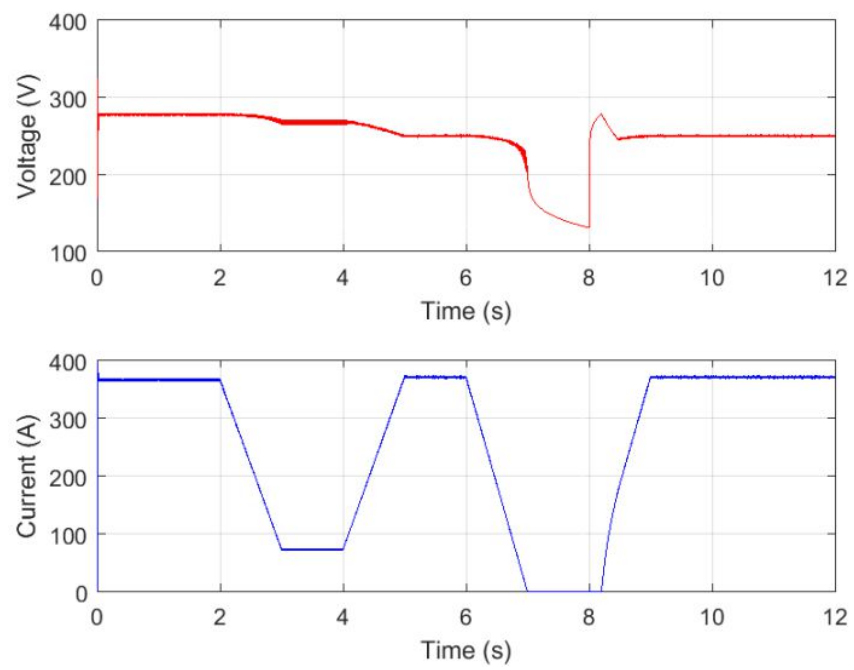

Fig. 4. Voltage and current on PV panel w/o storage system.

Figure 5 presents the power of the PV panel. A decrease in the power output for the increase of the temperature is observed. Voltage and current delivered to the electric grid are shown in Fig. 5, where it can be seen that the voltage remains practically constant, with variation occurring only in the current. The base is $25 \mathrm{kV}$ and $3.01 \mathrm{~A}$.

The power generated by the PV panel and the power supplied by the battery are shown in Fig. 7. It can be seen when the battery power is negative, indicating charging phase, absorbing power from the panels. When the power is positive the battery is providing power to the system, i.e., its discharge over time is also evident.

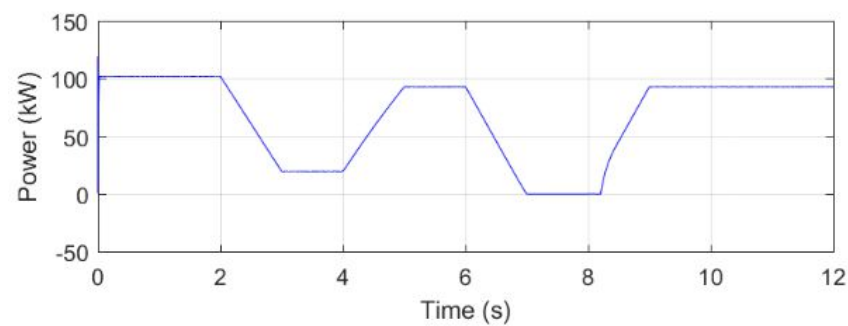

Fig. 5. Generated Power from PV

For the case 2, when connecting the Lithium-Ion battery to the PV system, the voltage and current profile are those depicted in Fig. 6, since the irradiance and temperature are the same.
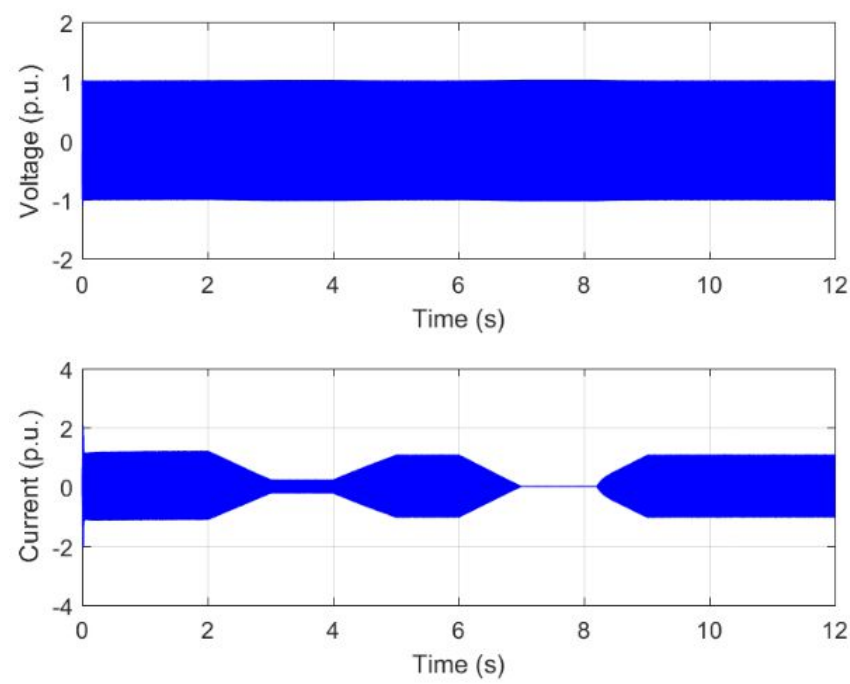

Fig. 6. Voltage and current delivered to the grid.
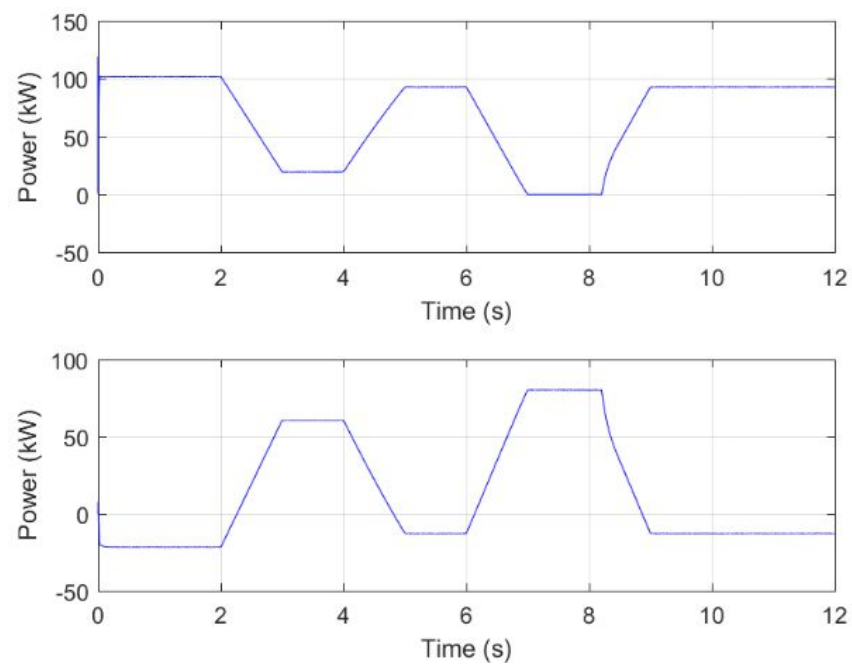

Fig. 7. Power generated from PV and power in the battery.

Figure 8 shows the voltage and current in the battery bank. The voltage remains almost constant, despite small variations throughout its discharge cycle. The current is controlled as a function of the power demand, varying in this way according to the PV generation. The battery allows the complementation of the generation to sweep the power injected into the network. 
When the generation of the PV panels is greater than $80 \mathrm{~kW}$, the surplus is stored in the batteries, and the current is negative. For generation lower than $80 \mathrm{~kW}$, the battery discharges the stored energy and the current is positive.
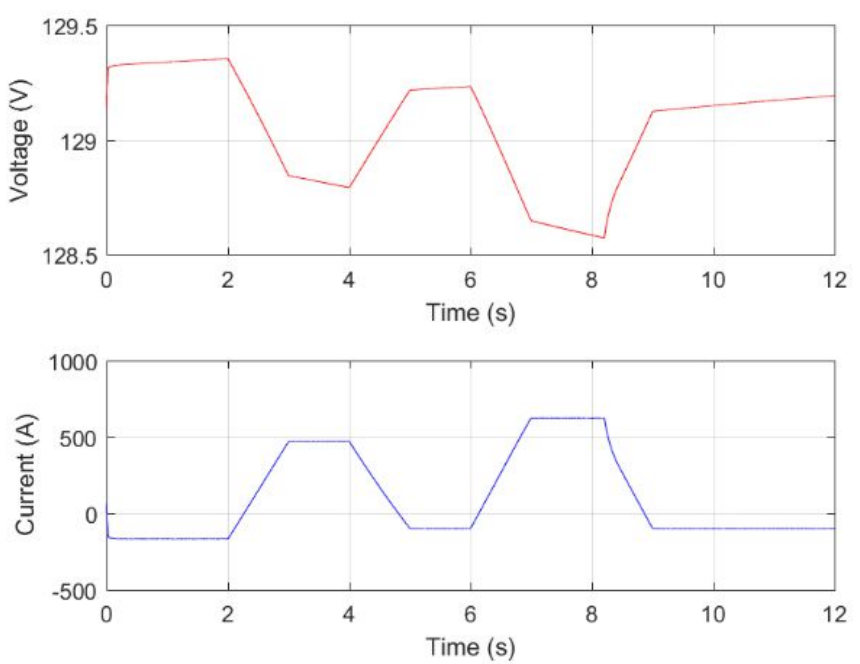

Fig. 8. Voltage and current with BESS.

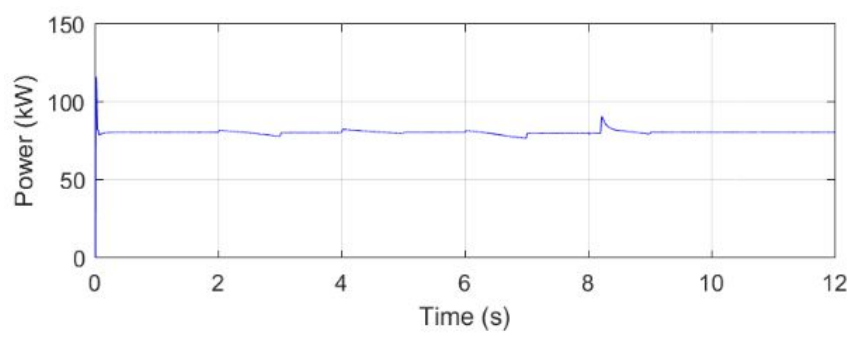

Fig. 9. Power delivered to the grid.
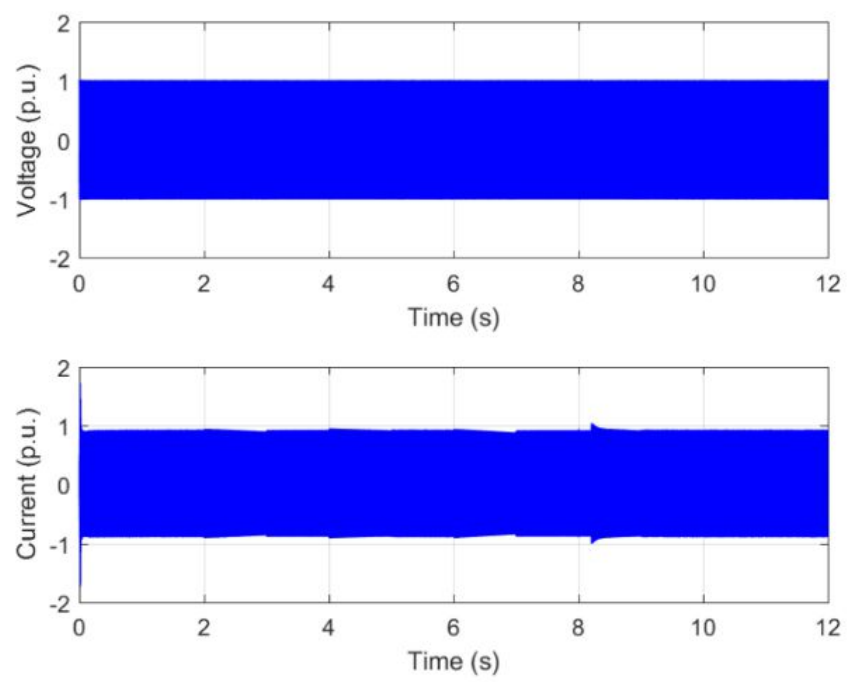

Fig. 10. Voltage and current delivered to the grid.

Figure 9 shows that the power generated by the panel along with the battery is constantly $80 \mathrm{~kW}$, thanks to the performance of the control of this system that connects the battery in the periods of little or no PV generation. In Figure 10 it is shown the voltage and current (p.u.) delivered to the grid. It is observed that the voltage and current remain constant when compared to the system without the battery. The base voltage is $25 \mathrm{kV}$ and the base current is $3.01 \mathrm{~A}$.

\section{CONCLUSIONS}

The generation of electricity from a photovoltaic system depends on the climatic conditions of the region in which it is installed. By decreasing solar irradiance, which may occur by the presence of clouds between the sun and solar panels, for example, the power generated also decreases. The current absorbed by the load and consequently the power curve generated by the PV have smoothed variations due to the use of energy storage, which delivers energy into the system, until the PV restores its output. The use of an effective control in the generation system is essential to keep the supplied power as constant as possible. With the modeling and simulation carried out it was possible to keep the generation of PV $80 \mathrm{~kW}$ continuously as proposed by minimizing the impacts of intermittency of solar generation and increase the reliability of the system.

\section{ACKNOWLEDGMENTS}

The authors appreciate CNPq, CAPES, INERGE, and FAPEMIG for their continuous support to develop research.

\section{REFERENCES}

[1] MME. Ministério de Minas e Energia. "Energia Solar no Brasil e Mundo - Ano de referência 2016”.MME, pp 5, 2017.

[2] F. A. Farret, M. G. Simões, "Integration of Alternative Sources of Energy," John Wley \& Sons. 2006. Pp. 262-295.

[3] I. A. Raihan. "Impact of Energy Sorage Devices on Relibility of Distribution System," 2nd International Conference on Electrical, Computer \& Telecommunication Engineering (ICECTE). 2016.

[4] A. A. Akhil, G. Huff, A. B. Currier, B. C. Kaun, D. M. Rastler, S. B. Chen, A. L. Cotter, D. T. Bradshaw,W. D. Gauntlett, "DOE/EPRI 2013 Electricity Storage Handbook in Collaboration with NRECA," Sandia National Laboratories. Albuquerque, p. 163. 2013.

[5] P. A. Ribeiro, B. K. Johnson, L. C. Mariesa, A. Arsoy, Y. Liu. "Energy Storage Systems for Advanced Power Applications," Proceedings of the IEEE, vol.89, No. 12, 2001.

[6] IRENA - International Renewable Energy Agency. Battery Storage for Renewables: Market Status and Technology Outlook. Published: January of 2015 .

[7] Kim, J., Suharto Y., Daim T. U., "Evaluation of Electrical Energy Storage (EES) technologies for renewable energy: A case from the US Pacific Northwest," Journal of Energy Storage 11 (2017) 25-54.

[8] B. F. Nunes, Y. F. F. C. Silva, E. C. Bortoni. Optimized selection and operation of electrical energy storage systems. 2015 IEEE Power \& Energy Society General Meeting. Denver/CO.

[9] J. Intrator, E. Elkind, A. Abele, S. Weissman, M. Sawchuck, E. Barllet, "2020 Strategic Analysis of Energy Storage in California," University of California, Berkeley School of Law, 2011.

[10] BBC News , "Tesla mega-battery in Australia activated". December of 2017. Available: http://www.bbc.com/news/world-australia-42190358

[11] K. E. Nielsen , M. Molinas, "Superconducting magnetic energy storage (SMES) in power systems with renewable energy sources," In: IEEE international symposium on industrial electronics. p. 2487-92.

[12] X. Luo, J. Wang, M. Dooner, J. Clarke. "Overview of current development in electrical energy storage technologies and the application potential in power system operation," Applied Energy, Volume 131, 1 january 2015, Pages 511-536.

[13] M. Welsch, "Europe's Energy Transition: Insights for Policy Making", 1st Edition, 2017. 354 p, p.175.

[14] ERRA-Energy Regulators Regional Association. Pumped Storage Hydroelectric Power Plants: Issues and Applications, Published: 2016

[15] F. Perez, J. F. Custódio, P.V. G. Souza, H. K. R. Filho, E. Motoki, B. D. Bonatto, P. F. Ribeiro, "Application of energy storage elements on a PV 
system in the smart grid context". IEEE PES Innovative Smart Grid Technologies Latin America, 2015.

[16] P. Giroux, G. Sybille, C. Osorio, S. Chandrachood, "Detailed model of a 100-kW Grid-Connected PV Array," Available: https://www.mathworks.com/help/physmod/sps/examples/detailedmodel-of-a-100-kw-grid-connected-pv-array.html,

[17] CEPEL, In Portuguese: "Centro de Referência para Energia Solar e Eólica Sérgio de Salvo Brito. Potencial Solar - SUNDATA," Available: http://www.cresesb.cepel.br/index.php\#data.

[18] J. I. L. Seguel. "Projeto de um sistema fotovoltaico autônomo de suprimento de energia usando técnica MPPT e controle digital". UFMG, pp. 222, 2009.

[19] M. E. M. Udaeta, G. P. Sampaio, J. L. de O. Bernal, R. Carneiro, F. Antonio, C. T. de A. Oliveira, L. C. R. Galvão, P. H. da. C. Rigolin, "Dimensionamento de um Sistema Fotovoltaico Residencial ZeroEnergia", GEPEA, USP, pp 34, 2014.

[20] A. P. C. Guimarães, C. M. Ribeiro, L. E. G. Bastos, L. C. G. Valente, P. C. D. Silva, e R. X. D. Oliveira, "Manual de Engenharia para Sistemas Fotovoltaicos”, CEPEL - CRESESB, pp 530, 2004.

[21] S. Adhikari, F. Li, "Coordinated Vf and PQ control of solar photovoltaic generators with MPPT and battery storage in microgrids,", IEEE Transactions on Smart Grid, v. 5, n. 3, p. 1270-1281, 2014.

[22] S. Sumathi, L. A. Kumar, P. Surekha, "Solar PV and Wind Energy Conversion Systems”. Springer International Publishing Switzerland, pp. 783, 2015.

[23] F. Perez, D. H. Pereira, L. B. Maciel, F. N. Belchior, P. F. Ribeiro, B. D. Bonatto, "Power Quality Analysis in Distributed Generation of a PV System with Energy Storage Elements". CIGRE C4 International Colloquium on EMC, Lightning and Power Quality Considerations for Renewable Energy Systems, 2016.

\section{BIOGRAPHIES}

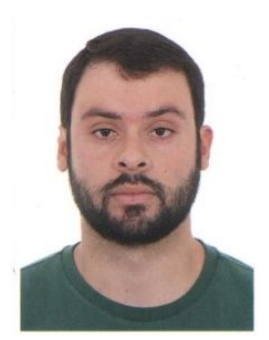

Paulo Alberto Viana Vieira was born in Itabira, Brazil, on April 16, 1987. In 2007 concluded Electrical Manitennace at Senai. In the following year, the Technical course in Electronics at the Technical College Itabirano-FIDE. He received a degree in Electrical Engineering from the Federal University of Itajubá (UNIFEI), Itabira, Brazil, in 2015. He received a CAPES Scholarship in the Sciences without Borders program, studying electrical engineering at the University of Texas at El Paso in the USA (2nd / 2014 and $1^{\circ} / 2015$ ). Paulo did an internship at University of Florida, Gainesville, Florida. He worked as a Protection and Control Engineer at JCV Energia and is currently a Msc. student at the Center for Excellence in Energy Efficiency (EXCEN). His research interests include smart grids, energy storage, distributed generation, energy efficiency and power system protection.

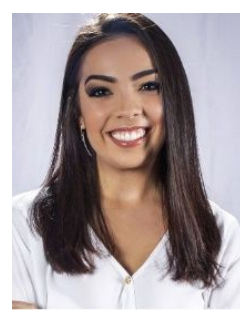

Bruna Pinheiro was born in São José dos Campos in 1993. She studied electronics technician at ETEP faculdades in 2008 and worked as an intern at Rockwell Collins do Brasil Ltda. In 2012, she started her studies at Universidade Federal de Itajubá and obtained a bachelor in Electrical engineering (2012- 2016). During this period, she participated of a Schweitzer Engineering Laboratories program called Embaixadores SEL, developed research in generators protection and worked in an electrical vehicle project. In 2017, she started studying in master's program at UNIFEI and nowadays works at Embraer S.A.

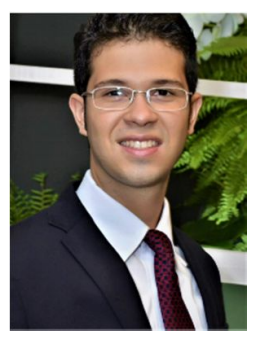

Filipe Perez received his B.Sc. degree in electrical engineering from Federal University of Viçosa, Viçosa, Brazil, in 2013, and his M.Sc. degree in electric power systems at Federal University of Itajubá, Itajubá, Brazil, in 2015. Since 2016 he is pursuing the double $\mathrm{Ph} . \mathrm{D}$. degree in nonlinear control of microgrids at École CentraleSupélec with L2S laboratory, France and Federal University of Itajubá, Brazil. His research interests are nonlinear control applied to power systems, microgrids, integration of renewable energies, energy storage systems, distributed generation and power quality.

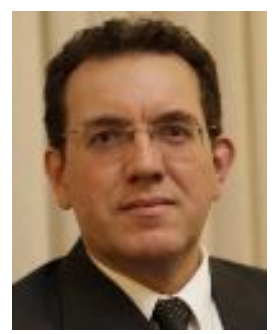

Edson da Costa Bortoni (S'94-M'96-SM'05) was born in Maringá, Brazil, on December 1, 1966. He received the Electrical Engineering degree from Itajubá Federal University (UNIFEI), Itajubá, Brazil, in 1990; the M.Sc. degree in energy systems planning from the University of Campinas, Campinas, Brazil, in 1993; the D.Sc. degree in power systems from the Polytechnic School of the University of São Paulo (USP), São Paulo, Brazil, in 1998; and the Academic Scholar degree (Habilitation) from USP, São Carlos, Brazil, in 2012. He was a Visiting Professor at Amazon University, Manaus, Brazil, and Adjunct Professor at São Paulo State University, Guaratinguetá, Brazil, and a Visiting Scholar at École Polytechnique Fédérale de Lausanne, Switzerland. He is currently a Professor at UNIFEI. Dr. Bortoni is a member of the Editorial Committee of the IET Generation, Transmission and Distribution, and of the Flow Measurement and Instrumentation Journals. His research interests include electrical machines, instrumentation, power generation, smart grids, and energy systems. Dr. Bortoni is a Senior Member of the International Society for Optical and Photonics, and a Fellow Member of the Instrument Society of Automation and of the Energy Efficiency Excellence Center. 